\title{
WHICH HISTORICISM IN THE MACINTYRE'S THOUGHT?
}

\author{
Qual historicismo no pensamento de MacIntyre?
}

Nicoletta Concu

University of Cagliari, Italy

\begin{abstract}
There was the-morality-of-fourth-century-Athens, there were the-moralities-ofthirteenth-century-Western-Europe, there are numerous such moralities, but where

ever was or is morality as such?

A. Maclntyre, After Virtue, p. 266
\end{abstract}

\begin{abstract}
Sumário: Reavaliando alguns escritos de Maclntyre, o artigo tenta extrair, no pensamento do filósofo escocês, os principais traços do tipo particular de historicismo desenvolvido por Maclntyre em oposiçao à metodologia de pesquisa perseguida pela "ortodoxia acadêmica". Na verdade, a ortodoxia acadêmica, responsável pelo estado de crise na cultura contemporânea, fracasso una tentativa de dar uma solução ao desacordo moral. Assim, era necessário explicitar outra perspectiva filosófica para resolver o desarcordo moral.
\end{abstract}

Palavras-Chave: historicismo, filosofia da ciência, neopositivismo, filosofia da ciência

Abstract: Looking back into some Maclntyre's writings my paper tries to achieve, in the thinking of the Scottish philosopher, the main features of the particular type of historicism developed by Maclntyre in opposition to the methodology of enquiry pursued by the "academic orthodoxy". Indeed the academic orthodoxy, responsible for the state of crisis in contemporary culture, fell down in attempting to give a solution for the moral disagreement. So it was necessary to pinpoint another philosophical outlook to solve moral disagreement.

Keywords: historicism, philosophy of history, neopositivism, philosophy of science 


\section{The opposition to the academic orthodoxy}

According to William Frankena's definition macintyrean methodology of inquiry can deemed to be as a kind of historical inquiry aimed to establish a philosophical point of view ${ }^{1}$. However, this utterance controversially ascribed by Frankena to the macintyrean methodological point of view, actually means to suggest that historical dimension assumes great influence into the process of philosophical enquiry.

Even though some critics in this approach have seen a tendency to confuse the level of historical and social analysis with that of the forms of philosophical justification ${ }^{2}$, if you look more closely, it looks like the claim of a conception of historically determined rationality.

Such claim takes on the trait of a struggle against the tendency to remove from philosophical enquiry their reference to the history, which is a critique of the philosophical standpoint that in the Postscript to After Virtue Maclntyre indicates as an "academic orthodoxy". This point of view reflects the methodological position according to which we can study and analyze philosophical issues such as moral concepts merely by reflecting, namely by considering philosophical issues without their history. Moreover, for Maclntyre this approach hypostatizes or makes harsher philosophical themes.

What is clear is that behind these first suggestions is hidden the rejection of the logical positivist approach. According to Maclntyre, it is the accomplishment of the Enlightenment Project, based on the distinction between

\footnotetext{
${ }^{1}$ See A. Maclntyre, After Virtue: A Study in Moral Theory, 3rd edn. (including "Prologue: After Virtue after a Quarter of a Century"), University of Notre Dame Press, Duckworth, 2007, (hereafter AV) cit. p. 265 in which the author makes explicit reference to the William Frankena's review of AV published in Ethics, Vol. 93, No. 3 (Apr., 1983), pp. 579-587

2 The reference is to R. Frega, Le voci della ragione. Teorie della razionalità nella filosofia americana contemporanea, Quodlibet, Macerata 2009, cit. p. 90 
factual and moral statements, that is, the distinction between "is" and "ought"; and pursued in attempting to legitimize the encyclopedic system of knowledge and, at the same time, to release philosophy from false problems bound up with metaphysical standpoints.

Furthermore, as we know, according to the logical positivist programme, the validity of the knowledge and as a consequence the removal of any metaphysical view from the knowledge equipment, are obtained by applying on the system of knowledge the method of logical analysis of language ${ }^{3}$. Such application allows us to classify as pseudo-propositions all the statements that do not respect the so-called principle of empirical significance. It is worth reminding that according to this setting "[T]o be meaningful is to be testable, to be verifiable by sense-experience; to be unverifiable is to be meaningless" ${ }^{4}$.

This kind of methodological approach had led to look askance at that subject matter as history and in general humanities whose judgements were included out both from the set of tautological statements and from the set of empirically verifiable one. Nevertheless, for these statements left open the possibility to put them within the new system of knowledge only if it was possible their epistemological refoundation $^{5}$, that involved a reduction of value utterances to factual ones. For this reason it was essential keeping out from the analysis of humanities the becoming dimension and therefore it was necessary to consider them without reference to their history also because their history would not provided any hint about their own development.

As we well know, logical positivist supporters while reacting to the various form of neo-idealist historicism argued that the only possible enquiry could be just that tied to the analysis of the logical-formal structure of the statements, which

\footnotetext{
${ }^{3}$ The reference is to R. Carnap, The Elimination of Metaphysics Through Logical Analysis of Language, in A. J. Ayer (ed.), Logical Positivism, The Free Press, New York 1959, pp. 60-81

${ }^{4}$ A. Maclntyre, Modern German Thought, in Malcolm Pasley ed., Germany: A Companion to German Studies, Methuen, 1972, cit. p. 448

${ }^{5}$ It is enough recall the Neurath's physicalist programme.
} 
led to consider the history of the various disciplines as an accidental feature. And it is exactly this standpoint that Maclntyre emphasizes in opening of A Short History of Ethics while writes:

"[M]oral philosophy is often written as though the history of the subject were only of secondary and incidental importance. This attitude seems to be the outcome of a belief that moral concepts can be examined and understood apart from their history. Some philosophers have even written as if moral concepts were timeless [...] necessarily having the same features throughout their history"6.

Thus, according to the Scottish philosopher, the supporters of neopositivist epistemology, whom he links up to the supporters of academic orthodoxy, hold that analysis of ethical issues must set aside reference to the historical if it wants to remain into the encyclopedic system of knowledge. Therefore, the ethical enquiry should focus instead on the analysis of the logical-formal structure of moral concepts, whose setting leads us to consider the ethical issues as whether they had the same characteristics regardless of the reference to their history.

However, this methodological approach, which is expressed in a research of argumentative accuracy based on the introduction of logical rules although pursued to clarify ${ }^{7}$ and to provide stability and consistency to the knowledge by removing it from the mutability of the becoming - would have generated such a state of confusion that it is impossible to distinguish the conceptual difference between the Greek "triremes" and "steamships". Such confusion would have led to

\footnotetext{
${ }^{6}$ Maclntyre, A Short History of Ethics: A History of Moral Philosophy from the Homeric Age to the Twentieth Century, Macmillan Publishing Company, 1966; Routledge \& Kegan Paul, 1967; first Touchstone ed., New York 1996; 2nd ed. (including new "Preface"), Routledge, 1999, (hereafter SHE and quotation from Touchstone ed.), cit. p. 1

${ }^{7}$ The need of clarity in philosophical arguments is exposed by Moore in Principia Ethica (1903) and appreciated by other students of Cambridge like Keynes who describes Moore's book as "it was exciting, exhilarating, the beginning of a renaissance, the opening of a new heaven on a new earth" like to this regard MacIntyre relates in AV p. 14 where he quotes The Bloomsbury Group by SP Rosenbaum, Croom Helm, London, in 1975, but it is worth to note that the same reference is traceable in JM Keynes, My early belief in Essay and Sketches in Biography, New York 1956
} 
persist in translating the term "trireme" with the term "steamship"8, which according to Maclntyre portrays the "inability to confront the moral philosophy of the very culture inheritance from which made our own moral philosophy possible" ${ }^{\prime \prime}$, that is, the inability to understand where the current moral philosophy comes from.

In other words neo-positivist approach that in order to reach expositive and explicative clarity uses a kind of methodology that works by isolating, atomizing and abstracting arbitrarily philosophical issues from their relationship with the historical and cultural context, it would lead to unintelligibility of concepts and philosophical questions. In addition, in such a situation even the attempts of analytical approach aimed at the clarification of the meaning of philosophical language would be useless because they would only lead to the proliferation of rival theories featured by incommensurability.

Therefore, according to the macintyrean outlook, the methodological framework built by academic orthodoxy would be a negative way of addressing the research in the field of moral philosophy (and in general in the philosophical field). Because it would reduce ethical judgments to fragments and simulacra of morality, "deprived of any status that can secure their authority"10, that would have reduced them "to a rationally opaque collection rules"11.

Like the taboo of Polynesian culture ${ }^{12}$, whose meanings can be understood only as a residue of some previous cultural background, without whom

\footnotetext{
${ }^{8}$ See Maclntyre, SHE, p. 255 and the same example in R. G. Collingwood, An Autobiography, Clarendon Press, Oxford 1978 (ed. with a with a introduction by Stephen Toulmin), cit. p. 64

${ }^{9}$ A. Maclntyre, The relationship of philosophy to its past, in Richard Rorty, J.B. Schneewind \& Quentin Skinner eds., Philosophy in History: Essays on the Historiography of Philosophy, Cambridge UP, 1984, pp. 31-48, cit. p. 39

${ }^{10}$ A. Maclntyre, AV, cit. p. 112

${ }^{11}$ Ch. Lutz, Reading Alasdair Maclntyre's After Virtue, Continuum International Publishing Group, New York and London 2012, cit. p. 78

12 The reference to Taboo of Polynesian culture is obtained in AV chapter 9 where Maclntyre quotes among other Mary Douglas's Purity and Danger (1966). The argument of taboo is introduced in many other macintyrean writing like Notes from the Moral Wilderness (1958) and Why is the Search for the Foundations of Ethics So Frustrating?, Hastings Center Report 9:4, 16-22, 1979 (reprinted as A Crisis in Moral Philosophy: Why is the Search for the Foundations of Ethics So Frustrating? in Tristram H. Engelhardt Jr. \& Daniel Callahan eds., Knowing and Valuing: The Search for Common Roots, Hastings
} 
they would end up looking like a set of arbitrary prohibitions, similarly the intelligibility of ethical judgments is possible only to the extent which they are analyzed from the point of view of their historical development, namely by taking an account of the context, not as concepts as such. Indeed from the perspective of macintyrean enquiry, an epistemology such as that neoposivist one, which does not take an account of the historicity, discloses itself as a barren approach"13, as a point of view without "rational way of securing moral agreement in our culture"14.

From here springs the endlessness of the moral debate, rediscovered by the features of conceptual incommensurability of the rival premises whose each one appeals himself or herself to the claim of impersonality of these arguments, and last but not least, even to summarize the previous premises, by the lack of any reference to the historical feature of moral concepts. That means losing both the awareness of the influence of social and historical context within which such judgments are formed and to the awareness that evaluative utterance we use switch their meaning through the time ${ }^{15}$.

It is the spread of these aspects in contemporary culture that has prevented the comparison of theories in order to overcoming the moral disagreement and, at the same time, has reduced the justification of ethical principles to a matter of individual choice. Therefore, the strategic importance of the re-evaluation of the magnitude of the historicity identified by Maclntyre implies the awareness that so far overcoming of the intractable feature of the moral argument has been prevented by "the persistently unhistorical treatment of moral philosophy by contemporary philosophers in both the writings about and the teaching of the subject"16. This state of affairs would led us to consider the philosophers of the past and of course moral

Center, 1980, and in Daniel Callahan \& Tristram Engelhardt Jr. eds., The Roots of Ethics: Science, Religion, and Values, Plenum, 1981)

${ }^{13}$ See Maclntyre, AV preface where he talk about "Oxford armchair style", p. xvii

${ }^{14}$ Ivi, p. 6

${ }^{15}$ Ivi, pp. 8-10

${ }^{16}$ Ivi, p. 11 
philosophers "as contributors to a single debate with with a relative unvarying subjectmatter"17 and so their thought would acquired "a false independence from the rest of the culture"18.

Thus, from the perspective provided by Maclntyre, if the process of philosophical enquiry that leaves apart the history of concept, a process achieved by neopositivist epistemology, drove to a predicament so widespread that dominates every aspect of contemporary culture - as it is demonstrated by the emotivist culture - then for restoring the lost order it will be necessary underpin a kind of research open to the consideration of the historical dimension of philosophical questions, that is, one open to the historical and cultural context of the philosophical issues. And so doing one would avoid the quixotic study of morality-as-such whose pursuit would led to the improper translations of moral concepts of the past as for example the translation provided by Hare to the concept of akrasia ${ }^{19}$.

This leads to the awareness that it is never possible justification for a theory-as-such, in other words, a theory "is vindicated or fails to be vindicated only relatively to those of its predecessors with whom it has competed so far" ${ }^{20}$. This means that just because you can not elude your past, you must first engage in a genuine and authentic relationship of philosophy with its own history, with its past, that in macintyrean words means understanding the unacceptability of the position according to which "[T]he past will have become the realm only of the de facto. The present alone will be the realm of the de jure"21. It is a position that had led to analyze philosophical theories emphasizing only the quaestio juris, that is the normative aspect of the issues without addressing the quaestio factis, namely by omitting the historical

\footnotetext{
17 Ibidem. Even here Maclntyre is quoting Collingwood who about realist wrote that they "thought that the problems with which philosophy is concerned were unchanging" and that the ancient philosophers "had alla asked themselves the same set of questions, and had given different answers to them". Quotation from Collingwood, An Autobiography, p. 59

18 Ibidem

${ }^{19}$ The reference is the macintyrean controversy disclosed in The relationship of philosophy to its past op. cit. particularly pp. 35-39

20 Ivi, p. 44

${ }^{21}$ Ivi, p. 39
} 
and cultural framework that leads to the awareness that "understand each philosophy in terms of the historical context of tradition, social order, and conflict out of which it emerged"22.

So then, in an effort to remove from philosophical enquiry what is considered the process of nullification, Maclntyre, who although brought up in a predominantly analytical cultural environment, he joined with the historicist culture through the mediation of Collingwood, proposes a rapprochement of philosophy and philosophical concepts to their history, and this engagement with the history leads us to classify his thought as a form of historicism.

Although such a classification, at first sight, calls to the mind the forms of neo-idealist historicism developed in opposition to the anti-historicist positions supported by neo-positivists, I will show that the macintyrean perspective about the historical knowledge is so far from reductionist orientation as well as from the orientation of contemporary German historicism, which developed itself in opposition to the romantic and providential conception of history and of course in opposition to Hegelianism, and that had set itself the goal of identifying the validity of historical and social disciplines).

For this reason, in the next section I will try to trace in macintyrean thought the preliminary course of rehabilitation of the historical knowledge pursued by the Scottish philosopher by closely following the epistemological debate that at first started up at the beginning of the twentieth century on the question of the scientific nature of history, and then with a decisive change of course in the second half of the twentieth century, it comes to the question of the historicity of science.

Indeed it is above all to this debate that Maclntyre turns his attention to vindicate not only the historicity of the enquiry in the field of ethics but also to vindicate the historicity of philosophical research in general, that implies the

\footnotetext{
${ }^{22}$ A. MacIntyre, Whose Justice? Which Rationality? University of Notre Dame Press, Notre Dame, Indiana 1988, cit. p. 390 (hereafter WJ?)
} 
acknowledgement of the role that historical knowledge can play for solving philosophical disputes.

\section{Some stages of the renewal process of historical knowledge into the philosophical enquiry}

Maclntyre is well awareness that rehabilitation process of historical knowledge, which implies the recognition of the epistemological validity of a generic form of historicism understood in terms of "appealing to the historical consideration as a fundamental tool [...] of understanding, if not of the reality, at least of the manifestations of the life of men"23, namely, in the specific case examined by Maclntyre, appealing to the historical reflection as an instrument of rational justification of the superiority of one theory over the another ${ }^{24}$, in primis and foremost it requires a critical deliberation about that form of historicism rejected by neopositivists, because of its absolutist tendency that either had hindered the autonomy of human being making the human subject overawed by the inexorable historical process or was no able to give a full account of the kind of relationship that can establish between human being and the situation or context $\mathrm{t}^{25}$.

Needless to say that undoubtedly it is the historicist vision accepted and widespread in the neopositivist environment by Karl Popper, who in The Poverty of Historicism (1944-45) uses the term historicism to label a set of philosophical doctrines that conceive the history as an inevitable becoming governed by laws that make the future course of events predictable and inevitable.

\footnotetext{
${ }^{23}$ cfr. P. Rossi, Storicismo, in Filosofia (a cura di G. Preti), Enciclopedia Feltrinelli Fischer, $3^{\wedge}$ ed. it. 1972, pp. 446-472 - Philosophie, 1958 Fischer Bücherei KG, Frankfurt am Main und Hamburg, cit. ed. it. p. 449 ${ }^{24}$ See A. Maclntyre, AV chap. 19 Postscript to the second edition, particularly "The Relationship of Philosophy to History" pp. 265-272, especially pp. 268-9

Same position in WJ? where Maclntyre puts the question "How ought we to decide among the claims of rival and incompatible accounts of justice competing for our moral, social an political allegiance?", p. 2

${ }^{25}$ This issue is well treated by Pietro Rossi, Storicismo e storicità, in /l problema della filosofia oggi, Atti del XVI Congresso Nazionale di Filosofia (Bologna 19-22 Marzo 1953), Fratelli Bocca, Roma-Milano 1953, pp. 93-100, that remains a good point of reference on the studies about historicism.
} 
It is worth noting that Maclntyre keeps away himself from this understanding of history in Notes from Moral Wilderness (1958) that, written with the aim to release the Marxist view of history from the interpretation that of it had provided Stalinism, it represents the first macintyrean engagement with the theme of historicity.

Although the main target of this macintyrean essay is focusing on the critique of the means-ends morality that is a counterpart not only of the Stalinist vision, which "identifies what is morally right with what actually going to be the outcome of historical development" ${ }^{26}$, but also of the Western vision of the social organization, here there are interesting ideas that allow us to provide an account in negative of historicism, namely, that allow us to understand what historicism should not be according to the macintyrean perspective.

First of all, it is interesting to note that in this paper the effort to restore methodological enquiry's honor that takes an account of historical dimension of knowledge (that is, the defense of the authentic historical materialism) passes through the recognition of the validity of the critique that Popper addresses to historicism understood as "this doctrine that historical development is governed by laws and that its future course is therefore predictable"27.

In this regard it should be noted, albeit broadly, that Popper's argument against the historicism and thus against the Marxism, grafted into the trunk of the epistemological debate against the inductivism, according to which the scientific efficiency's criterion rests on verification and testability of the theory, is mainly directed on the questioning of deterministic predictability of the necessary historical development that led to the establishment of a closed society ruled by absolute and not falsifiable laws.

\footnotetext{
${ }^{26}$ A. MacIntyre, Notes from the Moral Wilderness -1, in The New Reasoner 7, 90-100, 1958-59 cit. p. 91

${ }^{27}$ Ivi, p. 95
} 
So considering that for Popper "what makes [...] a theory scientific is that it is refutable, that it is open to falsification ${ }^{28}$, only the theories that have stood on the test of falsification, or that have hold out against repeated attacks of falsification may disclose themselves, as Maclntyre says, as "the best theory so far" 29 , but forasmuch as the criterion of falsifiability is not applicable to the historicist theories, they remain into the unscientific field.

Popper's criticism against the historicism is ultimately the opposition to the view of history understood as a process oriented towards a necessary end, as a mechanical and automatic process, heritage of those philosophies that had anchored the history to a providential view that, by subordinating the becoming to a final end, had put human action to a level of secondary importance compared with the activity of the spirit, conceived as a profound historical reality or truth that drives evolution.

Within this outlook, which corresponds to the classical Marxist standpoint, the role of the human being is reduced to that of a simple spectator of the historical development of which he or she can know the structure and functioning but cannot interfere with it or change it. In other words, human beings through a process of objectification of historical reality are able to know it by seizing the laws governing the becoming, but in any way they cannot interfere on the future course of events with their actions.

However, that theory of history in which the human being is somehow overwhelmed by the historical development, according to Popper corresponds with Marxism, and in the macintyrean standpoint it is nothing but the doctrine defended by Stalin. Therefore, the effort of Maclntyre is now to exhibit that the doctrine properly attacked by Popper is not Marxism but Stalinism, a doctrine that, by bringing back Marxism to the argument according to which "a given level of technology and form of production as a basis produces a given form of social life and consciousness" ${ }^{\prime 30}$, it

\footnotetext{
${ }^{28}$ A. Maclntyre, Modern German Thought, op. cit. p. 449

${ }^{29}$ A. Maclntyre, AV, cit. p. 277, italic in the text.

${ }^{30}$ A. Maclntyre, Note from, cit. p. 97
} 
would have misunderstood the authentic setting of historical materialism by reducing the historical development to a predictable and inevitable pattern.

To this regard, the young Maclntyre who seems to have understood the extent of the debate that has been developed around the problem of the historical development after the publication and dissemination in the West of the Grundrisse ${ }^{31}$, in his paper of 1958, in an attempt to remove the deterministic view from historical materialism, he highlights how this misconceived standpoint of Marxism first of all rests on having established the parallelism between historical materialism and the Newtonian mechanics rather than on Darwinian evolutionism, a standpoint that "does not entail that the future history of species is predictable"32.

Actually, the predictive character of historical materialism, offered by the Stalinist interpretation, found its justification on the conception of a mechanical or causal relationship between structure and superstructure that instead was not considered by the Marxian view ${ }^{33}$. That also is put in evidence by the correspondence of 1881 with Vera Zasulich to whose request whether or not Russia shall emulate the West for achieving of communism, a position which it meant to retrace that inevitable pattern of development according to which we must pass from pre-capitalist society to capitalism and then to its overcoming, Marx had responded by stating that "[E]verything depends on the historical environment in which it occurs"34.

\footnotetext{
31 The Grundrisse der Kritik der Politischen Ökonomie that collects Marx's manuscripts from 1857 to 1858 was published first time in Moscow between 1939-1941, but they were unknown until 1952-3 when they republished in Berlin. This edition remained for a long time the only available translation in a west language, excepted the Italian translation of the 1956, like highlighted by E. J. Hobsbawm's preface of the Pre-capitalist economic formations (1965) translation of the important chapter of the Grundrisse, titled Formen die der kapitalistichen Produktion vorhergehen and then published separately where it is discussed the issue of pre-capitalistic historical development.

My source is the Italian edition Forme economiche precapitalistiche, Editori Riuniti, Roma 1956, II edizione del 1967 con introduzione di Eric J. Hobsbawm.

${ }^{32}$ A. Maclntyre, Notes from op. cit. p. 98

${ }^{33}$ See to this regard the E. J. Hobsbawm's preface to Forme economiche where he explicitly sustains that "there is nothing in Marx that authorize us to look for "General Law" of development that can explain the tendency of feudalism to evolve into capitalism", cit. p. 42 it. ed. (my translation)

${ }^{34}$ Karl Marx, Forme economiche op. cit., p. 160 
Marx's expression means to suggest that the economic structure, the basis, does not provide one determinate path of development, that obviously would diminish the historical development to a mechanical sequence of events steered by the generalization laws, but instead it provides "a framework within which superstructure arises, a set of relations around which the human relations can entwine themselves, a kernel of human relationship from which all else grows" ${ }^{35}$. For this reason it is no use considering "the doctrine that the basis determines the superstructure as a general formula" ${ }^{36}$ or as a law.

It is clear up to this point that the effort of renewal of historicist standpoint in that paper of 1958 rests on the argument against the deterministic conception, established since the seventeenth century and at a later stage persistently reaffirmed as a precondition of any investigation that would claim the achievement of the scientific level. In case of Marxism, this conception rests on the wrong mechanical relationship between structure and superstructure that it heads by defending a position according to which "human agency is essentially ineffective", because "[H]istory occurs [...] independently of human will and desire" ${ }^{37}$. By the epistemological point of view, the macintyrean disapproval is turned against the perspective that admits in some way the universality of the causal or mechanistic principle as a means of explanation, against which the Scottish philosopher had expressed his negative opinion in Determinism (1957), which states that:

[T] he discovery of causal explanations for our actions, preferences and decisions shows that we could not have done other than we have done, that responsibility is an illusion and the moral life as traditionally conceived a charade $^{38}$.

\footnotetext{
${ }^{35}$ A. Maclntyre, Notes from op. cit. 98

${ }^{36}$ Ivi, p. 99

37 Ivi, p. 96

${ }^{38}$ A. Maclntyre, Determinism in Mind vol. 66, n. 261, pp. 28-41, cit. p. 29
} 
To be impeached is primarily the Hume's account of causality according to which an event causes another event close to it if its occurrence is a necessary and sufficient condition for the occurrence of the next event that is the effect whose predictability is given by the consistency and uniformity of relationship that is established between antecedent and consequent.

And it is essentially to this form of epistemic determinism, according to which causality has been intended as a dyadic relationship ${ }^{39}$, that historical knowledge cannot be brought back, because causality is essentially "a relationship between at least four items ${ }^{\prime 40}$, although that has been ignored both by the supporters of Stalinism and by the supporters of the neopositivist programme of standardization based on a strong reductionist approach according to which the whole reality accessible to human being must use only a single method of analysis.

Therefore, Maclntyre is now committed to provide a positive account of the process of historical knowledge, which by the epistemological point of view means to reassert the contextualist conception of rationality and, by the methodological point of view, means to pinpoint into the historical and narrative structure a set of tools able to justify the rational superiority of one theory compared to the rival one.

For this reason, Maclntyre has been interested in the debate about the development of the post-Popperian epistemology, where the rediscovery of the historical dimension, overlooked when even trivialized by the previous neopositivist debate, presents itself as an indispensable element for the assessment of rival theories ${ }^{41}$ to the extent that " $[\mathrm{A}]$ theory always bears the marks of its passage through

\footnotetext{
39 See A. Maclntyre, Causality and History, in Juha Manninen and Raima Tuomela eds., Essays on Explanation and Understanding: Studies in the Foundations of Humanities and Social Sciences, Reidel, 1976, pp. 137-58, especially p. 142 and 147

${ }^{40}$ Ivi, p. 148 in which Maclntyre lists the four items we need having a causal explanation: "first of all that which intervenes, secondly that state of affairs which is interfered with by the intervention, thirdly the actual effect of the intervention and fourthly the outcome that would have prevailed but for the intervention".

${ }^{41}$ A firm position in this sense is in the L. Laudan perspective who in his famous essay Progress and its Problem: Towards a Theory of Scientific Growth (1977) we can read "non è possibile effettuare nessuna 
time $^{\prime 42}$. This quotation lead us to the first macintyrean engagement with the postpopperian epistemology, witnessed by his essay Epistemological Crises, Dramatic Narrative and the Philosophy of Science, which appeared in the issue of "The Monist" on October 1977 dedicated to "Historicism and Epistemology".

In this very important contribution, in which the author lays the methodological basis of his philosophy of history, it begins to take shape the centrality of the historical-narrative method, that here it characterizes the scientific problems and that it will be again affirmed for the narrative building up of the moral issues which he dealt with in the later writings and especially in the book of 1981.

It is evident that also this essay, in which Maclntyre expresses his interest for the season of changes that is affecting the philosophy of science, is part of the renewal process of the conception of history freed from dogmatism to which the previous tradition had bound it. All that means, on the one hand, to commit for making free the philosophy of history from the conception according to which historical development is characterized as a movement dependent either by some shape of consciousness that stands beyond history (i.e the hegelian idea of absolute spirit) or by some form of rigid legalism (i.e the neopositivist idea of generalization laws); and on the other hand aims to make free the history from the consideration of being "a repository for more than anecdote or chronology"43. Moreover, this engagement would recognize to the new concept of history a central role in the reflection on the progress of knowledge.

valutazione rilevante di una dottrina senza una ricca conoscenza del suo sviluppo storico", cit. a p. 227 dell'ed. it. in corsivo nel testo.

${ }^{42}$ A. Maclntyre, Epistemological Crises, Dramatic Narrative and the Philosophy of Science in The Monist, vol. 60 n. 4 pp. 453-72, 1977, reprinted in Gary Gutting ed., Paradigms and Revolutions: Appraisals and Applications of Thomas Kuhn's Philosophy of Science, University of Notre Dame Press, 1980; in Stanley G. Clarke \& Even Simpson eds., Anti-Theory in Ethics and Moral Conservatism, State University of New York Press, 1989; and in Alasdair Maclntyre, Selected Essays vol. 1: The Tasks of Philosophy, Cambridge University Press, 2006; cit. p. 11 from The Tasks of Philosophy (hereafter EC)

This important essay has been translated in Italian by S. Maletta and it has been included in his Biografia della ragione, Rubettino Editore, Soveria Mannelli 2007.

${ }^{43}$ Th. Kuhn, The Structure of Scientific Revolutions, by The University of Chicago Press, Second Edition Enlarged, 1970, p. 1 cap. I 
Nevertheless the macintyrean interest for the "new philosophy of science" is connected not only to the importance that the new setting of research gives to the historical dimension in the debate concerning the development of science, but also to the criticism that it is aroused against the value-freedom claim of scientific statements to which the new epistemology opposes the awareness that the facts are actually already value-laden, as Kuhn remembers when he writes "[...] the two groups of scientists see different things when they look from the same point in the same direction"44; a position that in the macintyrean process of renewal of the historical doctrine implies the awareness that history "is not an evaluatively neutral chronicle" 45 . The new setting of enquiry questioning the alleged neutrality of scientific speech is also highlighting the weaknesses of the neopositivist epistemic system founded on the conception of instrumental rationality that in order to ensure the objectivity and universality of knowledge or had reduced the historicist doctrine to a form of determinism or had removed from philosophical inquiry any reference to the historical becoming without realize, as Maclntyre points out, that:

Scientific reason turns out to be subordinate to, and intelligible only in terms of, historical reason. And, if this is true of natural sciences, a fortiori it will be true also of the social sciences ${ }^{46}$.

So from Maclntyre's outlook to hold the historicist perspective means to defend the rapprochement of philosophy to the history of philosophy, and the primacy of historical reason over scientific reason, which it implies the rejection of "conception of ideal rationality", that is, the rejection of "Enlightenment conception of "pure"

\footnotetext{
${ }^{44}$ Ivi, p. 150 cap. xii

${ }^{45} \mathrm{~A}$. Maclntyre, AV, p. 3. It is worth to notice that MacIntyre is reaffirming his distance from the academic orthodoxy according to which historical knowledge is nothing but a chronicle. Moreover it is significant the analogy with Benedetto Croce whose perspective has been diffused into the Anglo-Saxon culture by Collingwood.

${ }^{46}$ A. Maclntyre, EC, cit. p. 15
} 
rationality, divorced from considerations of time and place"47, a conception that "illegitimately ignores the inescapably historically and socially context-bound character" $^{\prime \prime 8}$.

To approve the historical reason means defending and recognizing that reality is always in becoming (in fieri), that reality is an uninterrupted process of historical development and this outlook implies the defense of the contextualist, practical and individualizing knowledge that leads our author to admit that philosophical concepts, that are forms of thought, cannot be separated from their historical and practical development.

Needless to remark at this point that the opposition that Maclntyre has portrayed on the epistemological level between scientific and historical reason, that corresponds to the opposition between instrumental and practical reason or in other words to the opposition between universalism and contextualism, it has its counterpart, on the methodological level, to the rejection of the explanatorypredictive methodology based on the causality's account as a dyadic relationship, to which Maclntyre opposes awareness of the need to pinpoint a new methodology appropriate to the understanding of the historical and procedural structure of reality.

Indeed, to the acknowledgement that reality is a cognitive category in becoming (in fieri) corresponds the awareness of the inadequacy of the methodology based on the principle of mechanical causality, and all this leads the author to look for an enquiry method that it takes into account the historicity in which the human being and the knowledge are immersed.

If it is true that for the rehabilitation of the historicity by the epistemological standpoint Maclntyre looks favorably to the debate developed into the philosophy of science, and especially to the work of Lakatos, who was trying to defend the theoretical value of the historicity within scientific enquiry when writes that "[P]hilosophy of science without history of science is empty; history of science

${ }^{47}$ J. Horton and S. Mendus Ed., After Maclntyre, Polity Press, Cambridge 1994, p. 4

${ }^{48}$ A. Maclntyre, WJ?, p. 4 
without philosophy of science is blind" 49 , there is no doubt that for the building of his methodological proposal Maclntyre is affected by the debate that has been developed within the field of the British analytic philosophy around the concept of historical explanation, especially as a result of resonance that in that environment had collingwoodian historicism, to which repeatedly Maclntyre refers.

Without going into details of the discussion, just because it is not the appropriate seat, nevertheless it seems to me right and proper to recall, although in broad terms, that into the Anglo-Saxon cultural scene the debate about the nature and the status of historical knowledge arose on the backdrop of analytic philosophy and on the need of argumentative rigor and that this debate had as protagonists philosophers that, swayed by collingwoodian consideration on historical knowledge and methodology, put in question the methodological monism supported by neo-positivists and reiterated by Hempel even after the revision of the his deductive-nomological model according to probabilistic vision ${ }^{50}$.

Although the questioning of this cognitive model, that is well suitable for the mechanistic worldview consolidated since the seventeenth century took place initially regard as the logical structure of historical explanation, the real opposition to the mechanistic worldview came after the narrativistic turn of the sixties that represents, beyond the defense of the peculiarities of historical knowledge based on the self-explanatory character of his propositions, the defense of a new vision of temporality as well as the knowledge.

In effect, to the structural conception of the time understood as a reversible order that allowed the application of a methodology of deterministic explanation of events always identical to themselves, to which corresponds an

\footnotetext{
${ }^{49}$ I. Lakatos, History of Science and its Rationals Reconstructions, in R. C. Burke e R. S. Cohen eds., P.S.A. 1970. In Memory of Rudolf Carnap, Boston Studies in the Philosophy of Science, vol. 8, Reidel Publishing House, 1971, pp. 91-135, cit. p. 91

${ }^{50}$ C. G. Hempel, The functions of General Laws in History (1942) e Explanation in Science and History, in Frontiers of Science and Philosophy, ed. R.C. Colodny, The University of Pittsburgh Press, Pittsburgh 1962, pp. 9-19
} 
epistemological conception that, in a sense, merely reflects the phenomena (the spectator theory of knowledge), it is set against a procedural conception of time understood as a direction, as irreversible process that needs a survey methodology that can capture in the present the past that it is encapsulated inside it, counterpart of the critical realist epistemological perspective.

According such a conception of temporality, the following of events can not be made intelligible through use of the explanatory-predictive method because the events arranged in a direction of irreversible appear inextricably linked to the specific circumstances of space and time and therefore they need of a methodology adequate to give an account of their structure. Indeed, if the reality is recognized as becoming, as historicity not reified or made absolute, then it will require a methodology of enquiry that is able to capture the vision of the diachronic development of reality.

What Maclntyre sustains through these suggestions is not only acknowledgement of narrative character of reality and historical knowledge but is also the claim of a historical-narrative method intrinsic to the enquiry, a position that opposes to the explanatory-predictive method a historical-narrative methodology capable of making intelligible phenomena without appealing to foreign elements, namely without elements that are outside from the narrative itself.

And this is the deep meaning of the macintyrean tradition-constituted and tradition-constitutive method of enquiry, whose application on every level of investigation (epistemological, ethical and social and anthropological) allows the full intelligibility of philosophical and ethical concepts because far away from hypostatizing those concepts it gives a rational account by inserting them in the respective contexts of reference and treating them as part of a whole. 


\section{Conclusion}

The attempt of reconstruction of the historicist approach to the philosophical enquiry in Maclntyre, is emerged through comparison with some minor works of the author, and it makes clear his strong anti-neopositivist orientation, developed in the effort to identify a method that can provide a rational response to the problem of moral disagreement, that means to pinpoint a criterion of rational choice between ethical rival theories.

Given in these terms the issue of disagreement reveals in primis the issue of a preliminary reflection on the concept of rationality. Which rationality must we appeal to for settling the moral disagreement? Given that the attempts carried out by an approach based on a pure, ideal and abstract concept of rationality did not provide the appropriate tools to ensure the overcoming of the moral disagreement, but on the contrary would led to the proliferation of conflicting theories and incommensurable traditions that make impossible the choice between rival bodies of theory, because the concept of incommensurability always suppose the lack of shared beliefs, it was necessary to give up on the concept of rationality that led to hypostatize philosophical concepts.

Therefore, given the problem of disagreement as a matter of historical development of the theories it was necessary to defend a contextualist conception of rationality that is able to grasp the procedural nature of reality and knowledge, which results in an attempt to make intelligible the becoming. These suggestions have prompted to put close the macintyrean epistemological outlook to that one of some philosophers of science like Lakatos (and the same Maclntyre does not deny this affinity) who by trying "to offer a way out of the Nietzschean scepticism [...] show how 
conceptual change can still be rational, even without any claim that one is thereby adopting an outlook that has a greater degree of absolute validity"51.

Indeed in the postscript to AV Maclntyre points out that he holds "not only that historical enquiry is required in order to establish what a particular point of view is, but also that it is in its historical encounter that any given point of view establishes or fails to establish its rational superiority relative to its particular rivals in some specific contexts" 52 .

Now it is exactly this acknowledgement of the possibility of choice between incommensurable traditions through the rational criterion that commits Maclntyre in the defense of a realist form of historicism that is able to sustain the rational choice between incommensurable theories or traditions in the extent that it is able to pinpoint a criterion of intelligibility of the failure of a tradition over the another. Only in this way the comparison between rival traditions, which is always in the Maclntyre's outlook, a comparison of conceptual schemes inner to each traditionresearch, may leave open the possibility "that in any particular field, whether the natural sciences or morality-and-moral-philosophy, or the theory of theory, some new challenge to the established best theory so far will appear and will displace it" ${ }^{\prime 53}$.

The theoretical effort that the author has to face, after highlighting the flaws of the "spectator theory" of knowledge, is to set out a theory of knowledge that can give a rational justification of the alleged superiority of one theory over another without falling down in some form of ethnocentric error that claims to rise their own values and own conceptual frameworks to a level of superiority over the rival values and schemata. In other words, the Maclntyre's effort is to be able to provide a rational justification for the Enlightenment project failure and likewise gives an account of the rational superiority of the Aristotelian-Thomistic tradition compared to other traditions-research, given their incommensurability or the lack of shared conceptual

${ }^{51}$ R. Stern, Maclntyre and Historicism in Horton and Mendus edts., After MacIntyre, Polity Press, Cambridge 1994, cit. p. 151

${ }^{52}$ A. Maclntyre, AV, p. 269

$53 \mathrm{Ivi}$, p. 270 
frameworks. For this reason the historicism defended by Maclntyre "involves a form of fallibilism; it is a kind of historicism which excludes all claims to absolute knowledge" ${ }^{\prime 54}$. 